\title{
Hematopoietic Cell Transplant Relapse High Risk Rate
}

National Cancer Institute

\section{Source}

National Cancer Institute. Hematopoietic Cell Transplant Relapse High Risk Rate. NCI Thesaurus. Code C103155.

Risk of hematopoietic cell transplant relapse rates per patient year with $\mathrm{p}$ value higher than 0.52 . 